\title{
LIFE CYCLE PROCESS MODEL OF A MARKET-ORIENTED AND STUDENT CENTERED HIGHER EDUCATION
}

\section{Artūras KAKLAUSKAS ${ }^{1} \bowtie$, Alfonsas DANIŪNAS ${ }^{2}$, Dilanthi AMARATUNGA ${ }^{3}$, Vilius URBONAS ${ }^{4}$, Irene LILL ${ }^{5}$, Renaldas GUDAUSKAS ${ }^{6}$, Maurizio D`AMATO ${ }^{7}$, Vaidotas TRINKŪNAS ${ }^{8}$ and Ieva JACKUTE் ${ }^{9}$}

${ }^{1}$ Department of Construction Economics and Property Management, Vilnius Gediminas Technical University, Sauletekio al. 11, LT-10223 Vilnius, Lithuania

E-mail: arturas.kaklauskas@vgtu.lt

${ }^{2}$ Faculty of Civil Engineering, Vilnius Gediminas Technical University, Sauletekio al. 11, LT-10223 Vilnius, Lithuania

${ }^{3}$ School of the Built Environment, University of Salford, Salford M5 4WT, United Kingdom

${ }^{4}$ Faculty of Civil Engineering and Architecture, Kaunas University of Technology, Studentu g. 48, LT-51367 Kaunas, Lithuania

${ }^{5}$ Department of Building Production, Tallinn University of Technology, Ehitajate tee 5, 19086 Tallinn, Estonia

${ }^{6}$ Martynas Mažuydas National Library of Lithuania, Gedimino ave. 51, LT-01504 Vilnius, Lithuania

${ }^{7}$ Department of Architecture and Planning, $1^{\text {st }}$ Faculty of Engineering, Technical University Politecnico di Bari, Via Calefati, 272 - 70122 Bari, Italy

${ }^{8}$ Department of Construction Economics and Property Management, Vilnius Gediminas Technical University, Sauletekio al. 11, LT-10223 Vilnius, Lithuania

${ }^{9}$ Department of Construction Economics and Property Management, Vilnius Gediminas Technical University, Sauletekio al. 11, LT-10223 Vilnius, Lithuania

Received 2 December 2011; accepted 4 September 2012

\begin{abstract}
There is not a single definition/explanation about market-orientation education. Two opposite definitions/explanations of pure market-oriented education (Cato, 2010) and social-market-oriented education (Amaratunga, 2009) are provided in the paper. Integrated multiple criteria analysis at the micro-, meso- and macro-levels are needed to increase efficiency of the market-oriented higher education reforms. Market-oriented higher education reforms management involves numerous aspects that should be considered in addition to making educational, pedagogical, didactical, economic, political and legal/regulatory decisions. These must include social, culture, ethical, psychological, environmental, technological, technical, organizational and managerial aspects. This article presents a Life Cycle Process Model of a Market-Oriented and Student Centered Higher Education (developed during BELL-CURVE (Built Environment Lifelong Learning Challenging University Responses to Vocational Education) project's activities) for such considerations and discusses certain composite parts of it. To demonstrate the application of this research, two Case Studies from Lithuania are submitted for consideration.
\end{abstract}

KEYWORDS: Life cycle process; Model; Market-oriented higher education; Student centered higher education; Micro-, meso- and macro-levels 


\section{INTRODUCTION}

Many countries around the world e.g. USA (Fairweather, 2000; ASCE, 2008; The Economist, 2005; Wooldridge, 2005), Spain (Troiano et al., 2007), UK (Whitty, 2008), Finland (West and Ylönen, 2010), Japan (Reiko, 2001), Australia (Meek and Wood, 1997), Sweden (Fotaki, 1999), Netherlands (Van Vught, 1997), Argentina, Chile, Colombia (Bertranou, 1999), etc. take up market-oriented higher education reforms. Researchers and practitioners from various countries (Lee et al., 2008; Kazaz et al., 2008; Alinaitwe et al., 2009; Park et al., 2010; Stukalina, 2010; Preidys and Sakalauskas, 2010; Kosareva and Krylovas, 2011; Lin et al., 2011) analyzed acquire knowledge and increased learning efficiency in built environment. In order to throw more light on the subject, further follow more detailed description of some above research.

Troiano et al. (2007) present the topic of the orientation of university curricula, the pressures that exist today as a response to the demands of the market, and examine specifically the transformation that has developed in Spain during the last two decades.

Whitty (2008) assesses the period following the 1988 Education Reform Act (ERA) and reflects on the main continuities and discontinuities in policy emphases since that Act. This assessment is used to show the significant continuities between Conservative and New Labour policies in terms of the drive for an essentially market-based education system.

Japanese higher education institutions have experienced major reforms in the 1990s. These reforms were voluntarily promoted by the universities, and were aimed at transforming research-oriented faculties, or research centered organizations, to teaching and student centered universities. However, at the turn of the millennium, a new reform movement emerged, more economic centered, more market conscious and more influenced by the policy shift toward deregulation. In the 21st century, Japanese higher education institutions will face retrenchment, post-massification, and globalization (Reiko, 2001). Reiko (2001) examines government higher education policy and Japanese higher education reform movements in the globalization and post-massification eras.

Assessment is a powerful force in schools as well as in tertiary education frameworks. Assessment processes influence the way students learn, as well as the content and the extent of their learning. They also affect the way teachers select and teach various types of content and, indirectly, the way they decide what not to teach. Assessment processes also affect the level and the quality of educational achievements, the learning strategies students develop, cultures of teaching and learning, teachers' professional image, and the self-image and motivations of the learners (Libman, 2010).

In Libman (2010) opinion, current testing practices often neglect the assessment of more complex thinking processes. If the ability to engage in complex reasoning is a desired outcome of higher education, assessments should challenge students to elaborate, make connections, explore assumptions and apply nonalgorithmic thinking. Alternative assessments are often intended to motivate students to take more responsibility for their own learning, to make assessment an integral part of their learning experience, and to embed it in activities that stimulate students' abilities to create and apply a wide range of knowledge, rather than simply engaging in acts of memorization and basic skill development. The simplest definition for alternative assessment is a form of assessment other than traditional assessments, such as multiple choice tests and other usual forms of classroom assessment. Such a definition leaves the door wide open for a range of assessment techniques. Examples of alternative assessment formats are: performance, portfolio, cooperative learning, self- 
evaluation, journals, simulations, exhibitions, among others (Libman, 2010). Libman (2010), suggests a look at the potential of inculcating alternative teaching and assessment methods that encourage students to take a more active role in their own learning and participate in the process of assessing what they have learned.

The penetration of Information and Communications Technology (ICT) in the education system constitutes a worldwide phenomenon, as almost all countries have redesigned or amended their educational policy in order to integrate ICT (Blignaut et al., 2010; Sánchez et al., 2011; Vanderlinde et al., 2012; Wiseman and Anderson, 2012). This integration is both a long-term and complex process. The main factor for the successful integration of ICT in education is the teacher themselves (Dagdilelis and Satratzemi, 2004; Donnelly et al., 2011; Prestridge, 2012; Sánchez and Alemán, 2011).

The term Didactic Scenario (D.S.) refers to a relatively complete description of a teaching lesson including not only the teachers' actions but also the expected reactions of the students. Various parameters are included in modern D.S. such as interaction and roles of participants, students' concepts and expected errors, didactical obstacles, and so on. In such a teaching approach it is possible to combine more than one source (variety of different software, notes, instruments in laboratory, geometrical instruments) so as to obtain a learning outcome (Dagdilelis and Papadopoulos, 2010).

Learning activities can follow different pedagogical approaches and didactic concepts. The main focus in technology-enhanced learning is on the interplay between these activities and respective technologies. This can range from enabling access to and authoring of a learning resource to elaborate software systems managing (e.g. learning management system, learning content management systems, learning repositories, adaptive learning hypermedia systems, etc.) and managing (human resource management systems; tools for self-directed learning, etc.) the learning process of learners with technical means (eNotes, 2010).

The authors of this paper took part in the project "Built Environment Lifelong Learning Challenging University Responses to Vocational Education" (BELL CURVE) and developed the Life Cycle Process Model of a Market-Oriented and Student Centered Higher Education.

The structure of this paper is as follows. Section 2, following this introduction, annotates two opposite definitions/explanations of market-orientation education. Section $3 \mathrm{ex}-$ plains the Life Cycle Process Model of a Market-Oriented and Student Centered Higher Education. Section 4 "Case Study 1: Emotions, Interesting in Learning and the Happiness Index: their Effect on Learning Outcomes" provides a practical realization a part of this model. Section 5 describes the relationship between self-expression values and academic achievements of students (Case Study 2). Finally some concluding remarks appear in Section 6 .

\section{TWO OPPOSITE DEFINITIONS/ EXPLANATIONS OF MARKET- ORIENTED EDUCATION}

There is not a single definition/explanation about market-oriented education. Two opposite definitions/explanations of pure market-oriented education (Cato, 2010) and social-marketoriented education (Amaratunga, 2009) are provided below.

The Cato Institute is an American libertarian think tank headquartered in Washington. The Cato Institute is a public policy research organization - a think tank - dedicated to the principles of individual liberty, limited government, free markets and peace. Its scholars and analysts conduct independent, nonpartisan research on a wide range of policy issues. The following Nobel Memorial Prize in Economic 
Sciences Honorees have worked with Cato: F. A. Hayek, Milton Friedman, James M. Buchanan, Robert Mundell, Edward C. Prescott, Douglass C. North, Vernon L. Smith, Gary S. Becker, Ronald Coase, Thomas C. Schelling (Cato, 2010).

The Cato Education Market Index (CEMI) attempts to measure how closely existing school systems resemble free markets and rates education policy proposals on how conducive they are to the rise of competitive marketplaces. CEMI defines an education market as a system that provides the freedom for producers and consumers to voluntarily associate with one another, as well as the incentives that encourage families to be diligent consumers and educators to innovate, control costs, and expand their services. The purpose of the CEMI is to rate existing school systems on the basis of how closely they approximate true free markets (CEMI call this a market rating) and to rate education policy proposals on their conduciveness to the growth of markets (a policy rating). The index takes a large number of details about a given system or policy as its input data and uses those data to produce a numeric score from 0 to 100 . This overall rating is computed by combining several subcomponent scores, which allows conclusions to be drawn about the specific strong and weak points of the school system or proposal under consideration. CEMI's design was guided by four principles: reliability, objectivity, comprehensiveness (content validity), and accuracy (predictive validity) (Coulson, 2006).

Social-market-oriented education definition/ explanation was used in the BELL-CURVE project's activities and current paper.

Most universities tend to offer the same courses to the same group of academically best-qualified young students and fail to open up to other types of learning and learners, e.g. retraining courses for graduates or gap courses for students. This has hindered the provision of training/retraining opportunities to increase skills and competency levels in the workforce and led to persistent mismatches between graduate qualifications and labour market skill needs. The mismatch between graduate skills and labour market requirements has been identified as one of the main factors behind graduate unemployment and employer dissatisfaction, particularly in the built environment, as reported by EU labour force survey 2008. In order to overcome this persistent problem, university programmes should be structured to enhance directly the employability of graduates and training/retraining programmes which include broader employment-related skills along with the more discipline specific skills. The aim of the BELLCURVE project is to promote the concept of 'lifelong university' in modernising HEI's to be more responsive to labour market skill needs. The main focus was on governance reforms in higher education institutions delivering BE programmes across the EU. The concept 'lifelong university' encourages graduates (employed/unemployed) to inform their university on labour market skill requirements, which will then provide the opportunity to acquire the right mix of skills for the labour market through training/ retraining programmes. The project developed a tested framework for HEI's to promote the concept of lifelong university in capturing and responding to labour market skill needs in the built environment. Thereby, universities should able to respond better and faster to the demands of the labour market through providing opportunities to different types of learning and learners (Amaratunga, 2009).

"Lifelong university" concept proposes an innovative way to promote the development of a high quality, high performance lifelong learning practice in HEIs. This project aims to facilitate the governance reforms of HEIs to capture and respond to the European construction labour market needs, thereby forming a lifelong learning feedback loop. Euro- 
pean dimension and the necessary promotion systems and practices for good governance for lifelong learning in European HEIs are therefore promoted. This project proposes advancements to the Built Environment Higher Education Area within the Europe. Since it creates strong links between the HEIs and the labour market skills needs this project will help to realise much needed advancements within the targeted European Higher Education Area. The intended link between construction labour market and the HEIs will force the higher education to stimulate innovation to overcome the challenges of the construction industry. The lifelong learning feedback loop will also help to identify any gaps between the higher education and vocational education which in turn will contribute to the process of innovation (Amaratunga, 2009).

\section{LIFE CYCLE PROCESS MODEL OF A MARKET-ORIENTED AND STUDENT CENTERED HIGHER EDUCATION}

Various models are being developed to justify the market-oriented higher education reform running in many developed countries worldwide (see e.g. Vrontis et al., 2007; Kimmitt, 2009; Gainer and Padanyi, 2005; Fairweather, 2000). The models may be econometric, status-attainment, combined (Hossler et al., 1989), etc.

Our research included the following stages:

Stage I. Comparative description of the market-oriented and Student Centered higher education (MOSCHE) lifelong concept and strategy in EU countries and in Lithuania:

- A system of criteria characterizing the efficiency of MOSCHE's lifelong concept and strategy is determined by means of using relevant literature and questionnaire.

- Based on a system of criteria, a description of the present state of MOSCHE's lifelong concept and strategy of EU coun- tries and Lithuania is given in conceptual (textual, graphical, numerical, etc.) and quantitative forms.

The success of American higher education and four scenarios and linked strategies for lifelong learning at the European level have been analyzed during $1^{\text {st }}$ Stage.

America boasts 17 of the world's top 20 universities, according to a widely used global ranking by the Shanghai Jiao Tong University. American universities currently employ $70 \%$ of the world's Nobel prize-winners, 30\% of the world's output of articles on science and engineering, and $44 \%$ of the most frequently cited articles. Why have European universities declined so precipitously in recent decades? And what can be done to restore them to their former glory? The answer to the first question lies in the role of the state. American universities get their funding from a variety of different sources, not just government but also philanthropists, businesses and, of course, the students themselves. European ones are largely state-funded. The constraints on state funding mean that European governments force universities to "process" more and more students without giving them the necessary cash-and respond to the universities' complaints by trying to micromanage them. Inevitably, quality has eroded. Yet, as the American model shows, people are prepared to pay for good higher education, because they know they will benefit from it: that's why America spends twice as much of its GDP on higher education as Europe does (The Economist, 2005).

The success of American higher education is not just a result of money (though that helps); it is the result of organisation. American universities are much less dependent on the state than are their competitors abroad. The US university system is very prestige oriented; whenever you state your degree, you immediately add the name of the school where you obtained it. The better US universities can afford to maintain high entry requirements, 
while schools lower on the list have to take all students they can get. By contrast, as example, the German university system is largely homogeneous and degrees are perceived to be equivalent (Wooldridge, 2005).

Four scenarios and linked strategies for lifelong learning at the European level are as follows (Strietska-Ilina, 2007):

- Competitiveness and splendid isolation (Divided Europe). Systemic divergences within and between countries remain and may be growing; education/training systems and providers are competing strongly; increasing polarisation and marginalisation of certain target groups, regions, sectors.

- Unity in diversity (Pick and mix Europe). The social and innovative role of education and training is recognised. However, no wider system development is taking place; systems and provisions develop only slowly towards mutual compatibility or transparency.

- Convergence without great coherence (Learning Europe). Despite prevailing divergences in the economy and society, converging regulations and provision are being developed, though the links to industry and private economy are largely missing. Efforts to ensure compatible rules and procedures at European level contribute little to increasing mobility and innovation. Systems and structures compete, and see European matters as peripheral.

- Balance and coherence (Towards a comprehensive European education and training system). The trend towards closer socioeconomic cooperation is confirmed through pro-active cooperation between European Member States and preaccession states in education and training. More people (young and old) gain higher levels of education and training. Resources are available through public and private funds. Systems develop in a comparable way. Qualification structures and educational/ training provisions become increasingly similar and compatible.

Bocoş et al. (2007) describe a base in selecting the usage model for the new technologies in education and in the structure of some competence standards ICT:

- The efficient didactic activity centered on learning is interactive, and it is based on the student's interaction with the information through diverse applications.

- The teacher's role is modified by the meaning of his development into a collaborator, team colleague, manager of learning situations, and designer of learning experience, tutor. The teacher's role is changed from a simple transmitter of knowledge, from a basic source of information for the students and for all the answers of their questions as an expert in the teaching subject, into a learning facilitator, trainer, mentor, co-participant in the students' learning activity.

- The student's role is modified equally from a passive receiver of information who has to memorize and to reproduce knowledge in a solitary way, into an active participant in the learning process itself. The student produces and classifies knowledge, participates also as a novice and also as an expert, depending of the situation, at the learning activity on class and cooperates with his colleagues to achieve the learning task.

- The educational process is focused more and more on the relation, investigation and research, becoming interactive and motivating.

- The success criterion is represented by the quality of understanding the learned things, the processing manner and the structure of data, the presentations quality, the result reference, beyond of achieving the objectives settled.

- The usage of the new technologies implies collaboration, communication, diverse ways to express, access to knowledge 
and relevant information, respecting everyone's rhythm and the style of learning, real learning contexts.

- The new learning environment offers sensorial stimulation (there are also implied others perception forms, the presentation are multimedia, audio - video) assure the development of the hole personality of the student.

Stage II. A comparison and contrast of MOSCHE's lifelong concept and strategy in EU countries and Lithuania includes:

- Identifying the global development trends (general regularities) of the MOSCHE's lifelong concept and strategy.

- Identifying MOSCHE's lifelong concept and strategy differences between EU countries and Lithuania.

- Determining pluses and minuses of these differences for Lithuania.

- Determining the best practice for MOSCHE's lifelong concept and strategy for Lithuania as based on the actual conditions.

- Estimating the mismatches between graduate qualifications and the needs of the labour market.

Stage III. A development of some of the general recommendations as how to improve the governance reforms in modernising HEI's to be more responsive to labour market skill needs.

Stage IV. Submission of particular recommendations for universities how they be able to respond better and faster to the demands of the labour market through providing opportunities to different types of learning and learners.

Stage V. Multiple criteria analysis of MOSCHE's lifelong concept and strategy components.

Stage VI. Performance of transformational learning and redesigning the mental and practical behaviour:

- Interested parties becoming aware and conceptualize of MOSCHE's practice- in-use and knowledge of worldwide best practice.

- Interested parties estimating the deviation between knowledge of worldwide best practice and MOSCHE's practicein-use.

- Performance of best practice learning.

- Fulfilling of best practice actions (understanding what the recurring motives caused manager' initial behaviour are; redesigning managers' core patterns of thought and behaviour).

- Performance of transformational learning (acquiring new manners of technological, social, ethical, etc. behaviour, get better understanding of how to interact with micro and macro environment) and redesigning the behaviour.

Stage VII. In order to augment the developed Model with the best global practice, the aforesaid stages are revised continually.

In order to throw more light on the Model, further follow more detailed description of two Case Studies:

- Emotions, interesting in learning and the happiness index (their effect on learning outcomes).

- Relationship between self-expression values and academic achievements of students.

\section{CASE STUDY - EMOTIONS, INTERESTING IN LEARNING AND THE HAPPINESS INDEX: THEIR EFFECT ON LEARNING OUTCOMES}

Scientists tried to ascertain to what extent the human brain could work before it approached the limit of "decreasing productivity" - that was how the scientists called the fatigue. The scientists, to their surprise, learned that the brain could work smoothly and efficiently after a workday of as many as eight or even twelve hours. Psychologists claim that fatigue much depends on the emotional and psychological state (Carnegie, 2004). Hadfield 
(1924) argued that the major part of fatigue is attributable to psychological causes.

Emotions may initiate, terminate, or disrupt information processing and result in selective information processing, or they may organize recall. Emotions have an effect on learning and achievement, mediated by attention, self-regulation, and motivation (Pekrun et al., 2007).

Boredom, spite, discontent, aimless rush, anxiety are the emotional factors which may emaciate people and reduce their productivity. Anxiety, tension and emotional disappointments are three most common causes of fatigue. Namely, they make people tired (Carnegie, 2004). Brill (1946) argues that people with sedentary jobs mostly become tired due to psychological and emotional factors.

The experience of pleasant and unpleasant emotions in academic situations is known to affect students' learning. The aim of the study was to extend previous research by examining the antecedents and consequences of student emotions in the homework context. Multilevel analyses of a longitudinal dataset containing 3483 grade 9 and grade 10 students in 155 classes showed that the perceived quality of the homework tasks assigned by the teacher affected students' experience of unpleasant homework-related emotions. Moreover, the experience of unpleasant emotions during homework sessions was negatively related to homework effort and negatively predicted later achievement in mathematics (Dettmers et al., 2010).

Pekrun et al. (2009) propose a theoretical model linking achievement goals and achievement emotions to academic performance. This model was tested in a prospective study with undergraduates $(N=213)$, using exam-specific assessments of both goals and emotions as predictors of exam performance in an introductory-level psychology course. The findings were consistent with the authors' hypotheses and supported all aspects of the proposed model. In multiple regression analysis, achievement goals (mastery, performance approach, and performance avoidance) were shown to predict discrete achievement emotions (enjoyment, boredom, anger, hope, pride, anxiety, hopelessness, and shame), achievement emotions were shown to predict performance attainment, and 7 of the 8 focal emotions were documented as mediators of the relations between achievement goals and performance attainment.

The authors of this article have looked into the dependences that link student grades with interesting in learning, happiness index, degree of stress, difficulty of studies, degree of fear; 114 built environment bachelor's degree graduates from Vilnius Gediminas Technical University (BSc programme "Construction Management", BSc programme "Real Estate Management"), Šiauliai University (BSc programme "Civil Engineering") and Klaipèda University (BSc programme "Civil Engineering") were selected for the survey.

The students had to fill in a questionnaire, which, on a 10-point scale, asked to assess the degree of interest in studies, the happiness index, degree of stress, difficulty of studies, degree of fear for each of the four academic years.

\section{Interesting in learning and the happi- ness index}

As an example, Table 1 shows the grades of three respondents (from 114 respondents) and the scores given to the degree of interest in learning by each module in each academic semester. These respondents are bachelors of a programme "Construction Management" from VGTU which are under finishing BSc thesis.

Almost all respondents marked the fourth year as the most interesting academic year and all respondents have the highest average grades in this year. This suggests that learning is far easier when the subjects are interesting and teachers know how to make them interesting. These, however, are not the only things that can lead to better learning outcomes. Sports may also be a factor. 
Table 1. The grades of three respondents (as example from 114 respondents) and the scores given to the degree of interest by each subject in each academic year (from 2007 till 2011)

\begin{tabular}{|c|c|c|c|c|c|c|c|c|c|c|c|}
\hline \multicolumn{4}{|c|}{$1^{\text {st }}$ respondent's assessment } & \multicolumn{4}{|c|}{$2^{\text {nd }}$ respondent's assessment } & \multicolumn{4}{|c|}{$3^{\text {rd }}$ respondent's assessment } \\
\hline $\begin{array}{l}2007 / \\
2008\end{array}$ & $\begin{array}{l}2008 / \\
2009\end{array}$ & $\begin{array}{l}2009 / \\
2010\end{array}$ & $\begin{array}{l}2010 / \\
2011\end{array}$ & $\begin{array}{l}2007 / \\
2008\end{array}$ & $\begin{array}{l}2008 / \\
2009\end{array}$ & $\begin{array}{l}2009 / \\
2010\end{array}$ & $\begin{array}{l}2010 / \\
2011\end{array}$ & $\begin{array}{l}2007 / \\
2008\end{array}$ & $\begin{array}{l}2008 / \\
2009\end{array}$ & $\begin{array}{l}2009 / \\
2010\end{array}$ & $\begin{array}{l}2010 / \\
2011\end{array}$ \\
\hline 7 & 5 & 6 & 5 & 6 & 10 & 5 & 5 & 7 & 10 & 5 & 6 \\
\hline 7 & 7 & 6 & 9 & 7 & 6 & 6 & 9 & 7 & 6 & 6 & 7 \\
\hline 5 & 5 & 8 & 9 & 6 & 8 & 8 & 9 & 5 & 8 & 7 & 8 \\
\hline 6 & 5 & 6 & 6 & 5 & 7 & 6 & 5 & 7 & 8 & 5 & 8 \\
\hline 9 & 8 & 6 & 10 & 8 & 9 & 10 & 8 & 5 & 10 & 8 & 9 \\
\hline 7 & 6 & 8 & 9 & 5 & 6 & 10 & 9 & 6 & 8 & 9 & 7 \\
\hline 6 & 7 & 6 & 9 & 6 & 9 & 10 & 9 & 7 & 5 & 8 & 9 \\
\hline 5 & 10 & 5 & 9 & 8 & 6 & 6 & 9 & 6 & 5 & 7 & 8 \\
\hline 8 & 8 & 5 & 9 & 8 & 5 & 9 & 9 & 7 & 5 & 7 & 5 \\
\hline 5 & 7 & 9 & 8 & 5 & 6 & 5 & 8 & 5 & 5 & 8 & 9 \\
\hline 7 & 6 & 8 & & 5 & 7 & 8 & & 6 & 7 & 8 & \\
\hline 5 & 6 & 6 & & 5 & 9 & 6 & & 5 & 6 & 7 & \\
\hline 5 & 8 & 8 & & 6 & 5 & 6 & & 5 & 5 & 6 & \\
\hline 6 & 6 & 6 & & 7 & 9 & 7 & & 6 & 7 & 6 & \\
\hline 5 & 6 & & & 6 & 5 & & & 7 & 10 & & \\
\hline 7 & 9 & & & 7 & 5 & & & 6 & 8 & & \\
\hline \multicolumn{4}{|c|}{ Average } & \multicolumn{4}{|c|}{ Average } & \multicolumn{4}{|c|}{ Average } \\
\hline 6,31 & 7,00 & 6,75 & 8,29 & 6,15 & 7,17 & 7,29 & 8,29 & 6,00 & 7,28 & 7,06 & 7,50 \\
\hline
\end{tabular}

Several respondents are known to have started playing sports either in the first or second semester of the fourth year; hence the benefits of sports are apparent and fully reflected in the academic achievement of our respondents. These three students have their annual average grade varying between 6.31 and 8.29, 6.15 and 8.29, 6.00 and 7.50 among all respondents, they also had the biggest increase of their average.

Aside from an interesting subject, happiness is also a significant factor affecting both the student and the student's academic achievement.

British scientists interviewed 1,000 people and, on the basis of their responses, invented the following formula (Health, 2003):

$$
\text { Happiness }=P+(5 \cdot E)+(3 \cdot H),
$$

where: $P$ stands for Personal Characteristics, including outlook on life, adaptability and resilience; $E$ stands for Existence and relates to health, financial stability and friendships;
$H$ represents Higher Order needs, and covers self-esteem, expectations, ambitions and sense of humour.

Questions on which the equation is based are as follows (Health, 2003):

1. Are you outgoing, energetic, flexible and open to change?

2. Do you have a positive outlook, bounce back quickly from setbacks and feel that you are in control of your life?

3. Are your basic life needs met, in relation to personal health, finance, safety, freedom of choice and sense of community?

4. Can you call on the support of people close to you, immerse yourself in what you are doing, meet your expectations and engage in activities that give you a sense of purpose?

We used this formula for happiness by the British scientists as a basis and asked the surveyed students four questions for each of the four academic years separately. Table 2 shows the answers of one respondent (on a 10-point scale). 
Table 2. The answers of one respondent (as exampled from 114 respondents) to the questions related to the formula for happiness

\begin{tabular}{lllll}
\hline & $2007 /$ & $2008 /$ & $2009 /$ & $2010 /$ \\
& 2008 & 2009 & 2010 & 2011 \\
\hline Question 1 & 7 & 7 & 8 & 8 \\
Question 2 & 6 & 6 & 8 & 9 \\
Question 3 & 8 & 9 & 9 & 10 \\
Question 4 & 7 & 8 & 8 & 9 \\
\hline
\end{tabular}

The answers (Table 2) were used in the formula for happiness (Health, 2003) to determine the parameters of the formula for the happiness index and the happiness indices for all four academic years. To illustrate, Table 3 shows the data of one respondent.

Table 3. The answers of one respondent to the questions related to the formula for happiness

\begin{tabular}{lllll}
\hline \multirow{2}{*}{ Parameters } & $2007 /$ & $2008 /$ & $2009 /$ & $2010 /$ \\
& 2008 & 2009 & 2010 & 2011 \\
\hline $\mathrm{P}$ & 13 & 13 & 16 & 17 \\
$\mathrm{E}$ & 8 & 9 & 9 & 10 \\
$\mathrm{H}$ & 7 & 8 & 8 & 9 \\
Happiness Index & 74 & 82 & 85 & 94 \\
$\begin{array}{l}\text { Happiness Index on } \\
\text { a 10-point scale }\end{array}$ & 7,4 & 8,2 & 8,5 & 9,4 \\
\hline
\end{tabular}

Figure 1 summarizes the research findings. It compares the curve positions of the annual average grades, the degree of interest in studies and the happiness index of the respondents.
Figure 1 suggests that the happier the person, the better the grades; it means that a happy student is better at assignments and research, needs less efforts to study, apparently is more productive and, consequently, gets better grades.

Another trend is also obvious: the more interested in studies, the happier the student is. Both factors are directly interdependent, which is obvious from the figure.

A comparison of the effect on grades by the interest in studies and the degree of happiness apparently reveals that both factors have a reasonable impact on the learning outcomes. The answers of the respondents, however, suggest that the degree of interest had a slightly bigger impact on grades than the happiness index, because, in the chart, the curve of the degree of interest rises faster and at a bigger angle, while the happiness index also climbed each year but at a rather steady pace (Figure 1).

\section{Degree of stress, difficulty of studies, degree of fear and academic achievements of students}

We shall analyze the stress and fear experienced by students as an example. Stress and fear positively and negatively affected academic achievements of students. A few examples are follows.

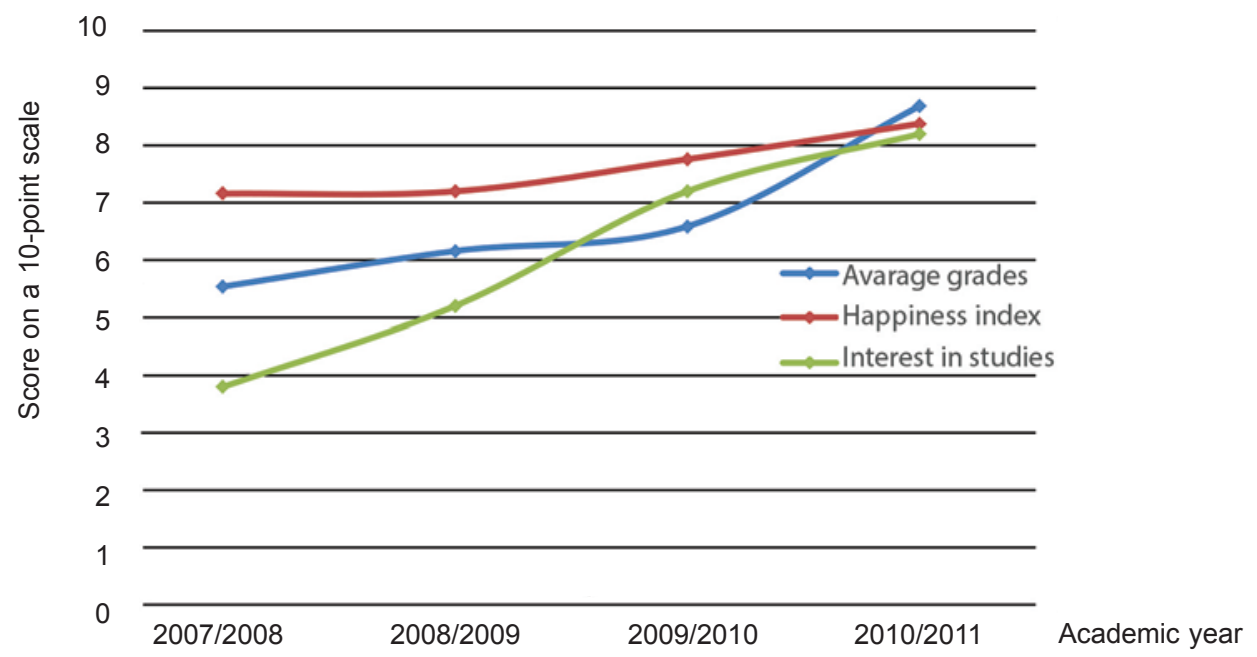

Figure 1. Variation of the happiness index, degree of interest in studies and the average grades throughout the studies 
According to Griffiths (1945), higher grades tend to be obtained by unsatisfactorily adjusted men; men with excellent health scores show a slight advantage over men with unsatisfactory health scores; men with brilliant scholastic records are not better emotionally adjusted than are those with lowest academic achievement; and unsatisfactory personality scores are not significantly correlated with unsatisfactory grades. Reducing students stress level through self-expression, helping them to discover strengths in nonacademic areas, providing them with social support, and aiding them in developing insight may help children grow psychologically and improve their behavior (Leichtentritt and Shechtman, 2009). Stress has a negative effect on student's memory, learning efficiency and emotional state. A stressed student finds it more difficult to understand the subject, assimilate knowledge and concentrate. Examinations are one cause of stress. Finding alternatives to the traditional assessment of student knowledge therefore would be an expedient move. Biometric technologies are an option.

According to Maslow (1954), freedom from worries about economic security has allowed people's needs for self-expression and for nonmaterial well being to become more prominent.

One of the main causes of fear is student loans or tuition fees. Most students started their studies with either partial or full state funding; some persons, however, had to pay the full tuition fee. The principle of rotation was also applied: each examination session determined the students who would have to pay part of the tuition fee and who would continue as state-funded students. Improving grades gradually relieve such fears, because a student with a high grade average is sure he or she will not have to pay for studies.

Figure 2 show that students had the lowest grade averages for their examinations in the first and second year, in contrast to the third and fourth year. Accordingly, the highest difficulty of studies was recorded in the first and second years. The degrees of stress, difficulty and fear were declining from the first year on. All these indicators were dropping because students felt more certain about their choice of the field of studies and learning was demanding less effort as more specialty modules were introduced, while the interest was also increasing. The drop of the degree of fear, however,

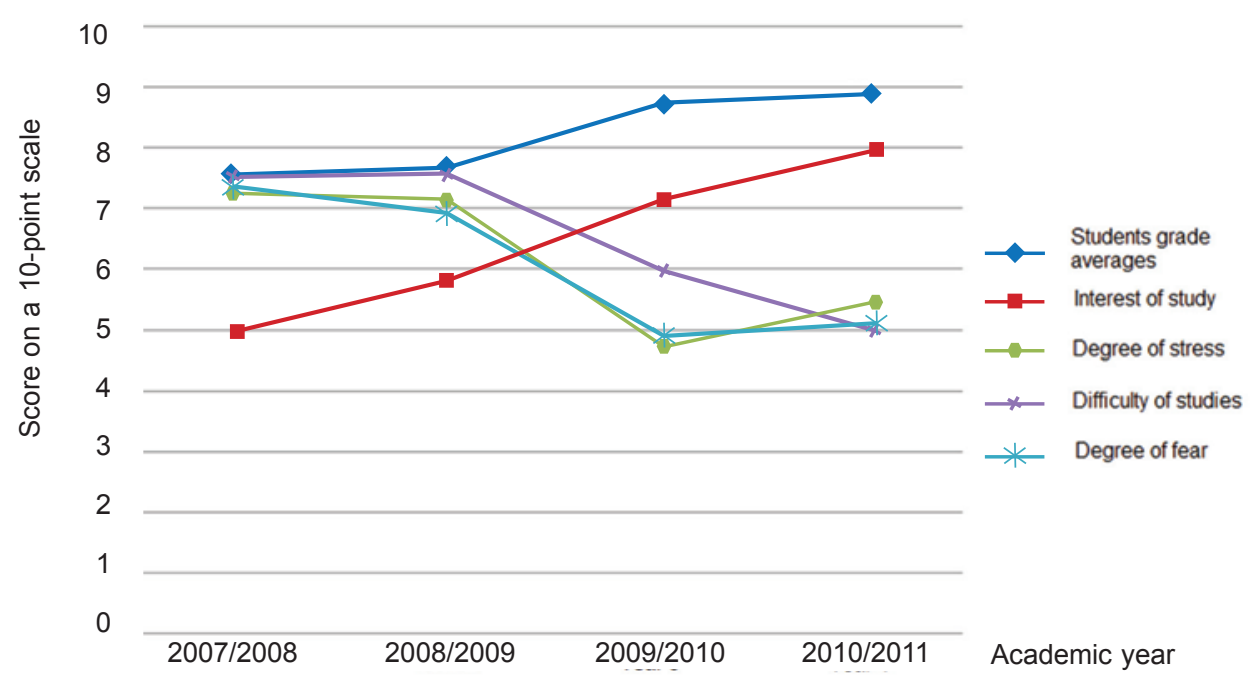

Figure 2. The dependence of student grade averages on the stress, difficulty of studies and fear 
was rather insignificant between the second and third years, because the second year was one of the most difficult and students feared for their results of credit tests and examination sessions. The highest degree of interest and the lowest degrees of fear, difficulty and stress were recorded in the fourth year; but it is worth pointing out that, compared to the third year, the degree of stress dropped only by 0.05 points. It may be attributed to the shortened examination session in the fourth year, when students were more loaded with work and had to write their final bachelor's theses.

\section{CASE STUDY 2: RELATIONSHIP BETWEEN SELF-EXPRESSION VALUES AND ACADEMIC ACHIEVEMENTS OF STUDENTS}

The World Values Surveys were designed to measure all major areas of human concern, from religion to politics to economic and social life. It turns out that two dimensions dominate the picture: (1) Traditional vs. Secular-rational values and (2) Survival vs. Self-expression values. These two dimensions explain more than 70 percent of the cross-cultural variance on scores of more specific values. The need for cognitive skills is dramatically larger than in societies in the early stages of industrialization. To meet these needs, the labor forces of postindustrial societies increasingly pursue higher education, emphasizing creativity, imagination and intellectual independence. The shift from survival values to self-expression values also includes a shift in child-rearing values, from emphasis on hard work toward emphasis on imagination and tolerance as important values to teach a child (see Figure 3). And it goes with a rising sense of subjective well-being that is conducive to an atmosphere of tolerance, trust and political moderation. Finally, societies that rank high on self-expression values also tend to rank high on interpersonal trust (Inglehart and Welzel, 2005).
Currently Lithuania conveys survival values according to the criterion of "self-expression values" as per World Values Surveys (see Figure 3). It can be claimed, on the basis of the aforementioned studies, that such a situation does not facilitate an effective academic achievement process. However, now the situation has shifted slightly toward self-expression values.

Researchers and practitioners from various countries (Vermillion et al., 2008; Breslow, 2007; Cheng, 2001a,b; Mok and Cheng, 2001; Cheng, 2002) analyzed the relationship between self-expression values and academic achievements of students. A few examples are following. Creativity in children at a young age is an efficient way to improve self-esteem, nurture self-expression and a key factor for future development in a child's academic achievements (Developing ..., 2010). All students need to communicate and express themselves effectively to develop a healthy self-concept and to succeed academically. Given the type of knowledge that is valued in our schools, poor communicators are often misunderstood, ostracized and in great peril of academic failure (Vermillion et al., 2008). In order to achieve academically students must possess self-determination: Self-determination encompasses a number of interrelated components that can be specifically taught as skill areas: (a) selfactualization, (b) assertiveness, (c) creativity, (d) pride and (e) self-advocacy. Therefore, in order for a student to make a successful transition into college, these skills should have been taught to the student at an earlier point in life (Breslow, 2007).

The key elements in effective learning and teaching are students and teachers' commitment, motivation and efficacy to promote and achieve learning as continuous self-actualization and self-learning and create unlimited opportunity for learning, developing learning groups, and evolving learning culture among 


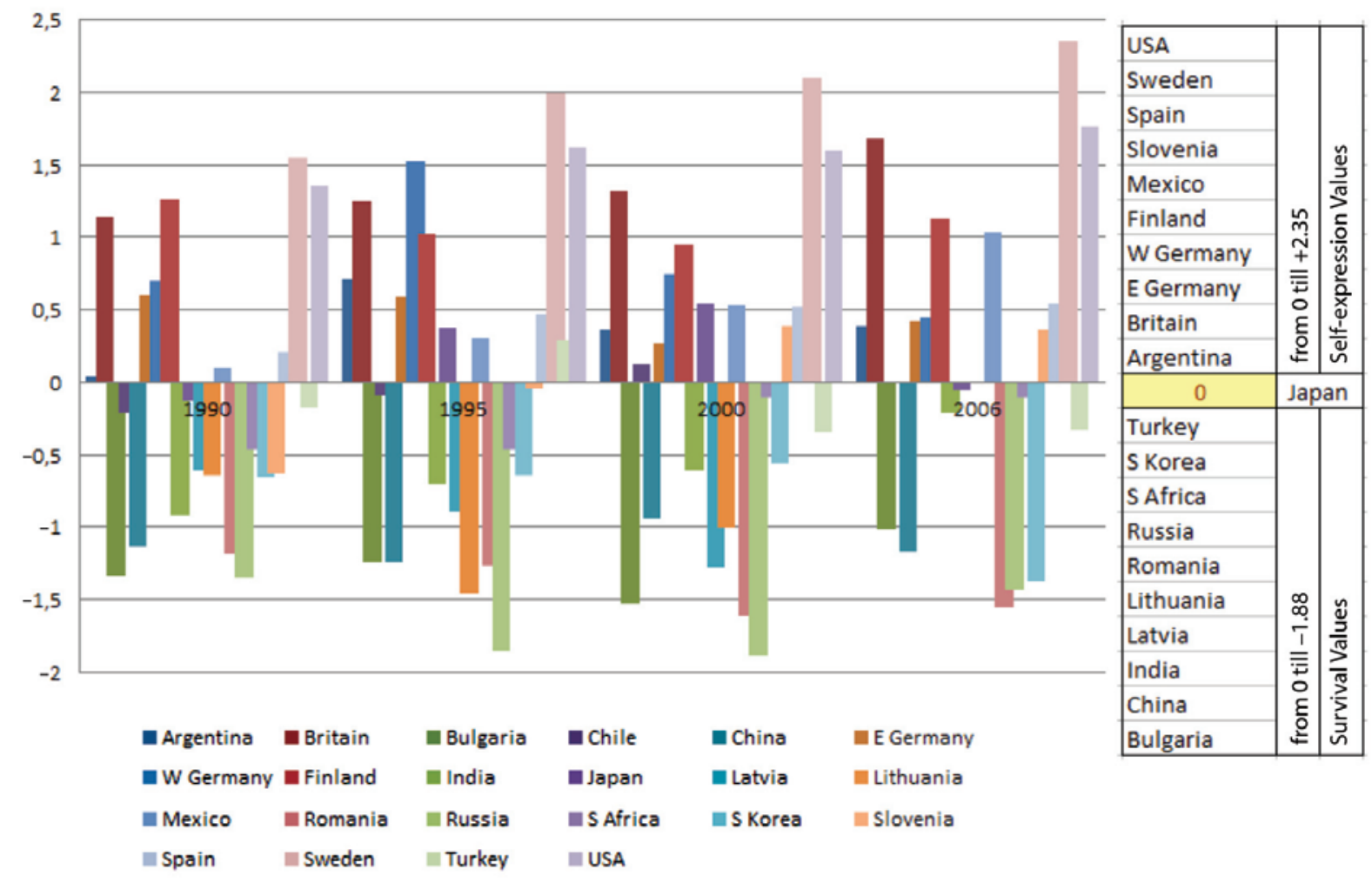

Figure 3. The shift from survival values (bottom part) to self-expression values (upper part) also includes a shift in child-rearing values, from emphasis on hard work toward emphasis on imagination and tolerance as important values to teach a child (World Values Surveys)

students and teachers (Cheng, 2001a,b; Mok and Cheng, 2001). Teaching is considered a process to initiate, facilitate, and sustain students' self-learning, self-exploration and self actualization; therefore, teachers or teachers should play a role as a facilitator or mentor who support students' learning. The focus of teaching is to arouse students' curiosity and motivation to think, act, and learn. Also, teaching is to share with students the joy of the learning process and outcomes. To teachers themselves, teaching is also a life long learning process involving continuous discovery, experimenting, self actualization, reflection, and professional development (Cheng, 2002).

\section{CONCLUSIONS}

There is not a single definition/explanation about market-oriented education. Two opposite definitions/explanations of pure marketoriented education (Cato, 2010) and socialmarket-oriented education (Amaratunga, 2009) are provided in the paper. The socialmarket-oriented education definition/explanation (Amaratunga, 2009) was used in the research. Researchers from various countries engaged in the analysis of the market-oriented and student centered higher education and its separate segments. However, they did not consider the research object being analyzed 
by the authors of the present research. This object may be described as a life cycle of the market-oriented and student centered higher education including involved stakeholders and the micro-, meso- and macro- environments, all of which have a particular impact on making an integral whole. The performed research explains the Life Cycle Process Model of a Market-Oriented and Student Centered Higher Education. Two Case Studies (Emotions, Interesting in Learning and the Happiness Index: their Effect on Learning Outcomes; the relationship between self-expression values and academic achievements of students) provide practical realizations a part of the Model.

\section{REFERENCES}

Alinaitwe, H., Mwakali, J. A. and Hansson, B. (2009) Organizational effectiveness of Ugandan building firms as viewed by craftsmen, Journal of Civil Engineering and Management, 15(3), pp. 281-288. http://dx.doi.org/10.3846/13923730.2009.15.281-288

Amaratunga, D. (2009) Built Environment Lifelong Learning Challenging University Responses to Vocational Education (BELL-CURVE). Erasmus. Application. Lifelong Learning Programme. Modernisation of Higher Education. $50 \mathrm{p}$.

ASCE (2008) Civil engineering body of knowledge for the $21^{\text {st }}$ century. Preparing the civil engineer for the future. Reston: American Society of Civil Engineers.

Bertranou, F. M. (1999) Are market-oriented health insurance reforms possible in Latin America?: The cases of Argentina, Chile and Colombia, Health Policy, 47(1), pp. 19-36. http://dx.doi. org/10.1016/S0168-8510(99)00006-8

Blignaut, S., Hinostroza, J. E., Els, C. J. and Brun, M. (2010) ICT in education policy and practice in developing countries: South Africa and Chile compared through SITES 2006, Computers and Education, 55(4), pp. 1552-1563. http://dx.doi. org/10.1016/j.compedu.2010.06.021

Bocoş, M., Glava, A. and Glava, C. (2007) Toward a conceptualization of e-didactics. In: ICT in edu- cation: reflections and perspectives, Bucharest, Romania, 14-16 June 2007, pp. 39-44.

Breslow, B. R. (2007) Exploration of experiences influencing the academic achievement of university students with learning disabilities in persistence to graduation. [Online] A thesis submitted to the graduate faculty in partial fulfillment of the requirements for the degree of Master of Science. Available at: http://gradworks.umi.com/1446135.pdf [accessed 17 October 2011].

Brill, A. A. (1946) Lectures on psychoanalytic psychiatry. New York: Alfred A. Knopf, Inc.

Cato (2010) Cato Institute. [Online] Available at: http://www.cato.org/about.php [accessed 15 December 2010]

Carnegie, D. (2004) How to stop worrying and start living. New York: Pocket Books.

Cheng, Y. C. (2001a) The strengths and future of Hong Kong education. Invited keynote speech at the conference of the leadership development network on "Facing up educational reforms: Leading schools for quality education", organized by the Asia-Pacific Centre for Education Leadership and School Quality, 20 October 2001.

Cheng, Y. C. (2001b) Three waves of education reform: Paradigm shifts for the future in Hong Kong. In: The $11^{\text {th }}$ World congress of comparative education, Chungbuk, Korea, 2-6 July 2001.

Cheng, Y. C. (2002) New paradigm of borderless education: Challenges, strategies, and implications for effective education through localization and internationalization. In: The international conference on learning and teaching, Hatyai, Thailand, 14-16 October 2002, pp. 34-91.

Coulson, A. J. (2006) The Cato Education Market Index, Policy Analysis, No. 585 December 14, pp. 1-24.

Dagdilelis, V. and Satratzemi, M. (2004) Training teachers in the didactic uses of ICT: more than fluency is needed. In: Ferdig, R. et al. (Eds.), Proceedings of society for information technology \& teacher education (SITE) international conference 2004, Chesapeake, pp. 4065-4068.

Dagdilelis, V. and Papadopoulos, I. (2010) Didactic scenarios and ICT: A good practice guide. In: Lytras, M. D. et al. (Eds.), Technology enhanced learning: Quality of teaching and educational 
reform, $1^{\text {st }}$ international conference, TECHEDUCATION 2010, Athens, Greece, May 19 21, 2010, Proceedings Series: Communications in Computer and Information Science, Vol. 73, pp. 117-123. http://dx.doi.org/10.1007/978-3642-13166-0_17

Developing your child's creativity with Alex Easels (2010) [Online] Available at: http://ezinearticles.com/?Developing-Your-Childs-CreativityWith-Alex-Easels\&id=5661030 [accessed 15 December 2010]

Donnelly, D., McGarr, O. and O'Reilly, J. (2011) A framework for teachers' integration of ICT into their classroom practice, Computers and Education, 57(2), pp. 1469-1483. http://dx.doi. org/10.1016/j.compedu.2011.02.014

eNotes (2010) Technology-enhanced learning. [Online] Available at: http://www.enotes.com/topic/ Technology-Enhanced_Learning [accessed 15 December 2010]

Fairweather, J. S. (2000) Diversification or homogenization: How markets and governments combine to shape American higher education, Higher Education Policy, 13(1), pp. 79-98. http:// dx.doi.org/10.1016/S0952-8733(99)00027-6

Fotaki, M. (1999) The impact of market oriented reforms on choice and information: A case study of cataract surgery in outer London and Stockholm, Social Science \& Medicine, 48(10), pp. 1415-1432. http://dx.doi.org/10.1016/S02779536(98)00446-8

Gainer, B. and Padanyi, P. (2005) The relationship between market-oriented activities and market-oriented culture: Implications for the development of market orientation in nonprofit service organizations, Journal of Business Research, 58(6), pp. 854-862. http://dx.doi. org/10.1016/j.jbusres.2003.10.005

Griffiths, G. R. (1945) The relationship between scholastic achievement and personality adjustment of men college students, Journal of Applied Psychology, 29(5), pp. 360-367. http://dx.doi.org/10.1037/h0055574

Hadfield, J. A. (1924) The psychology of power. New York: Macmillan. http://dx.doi.org/10.1037/10965-000

Health (2003) The formula for happiness. [Online] Available at: http://news.bbc.co.uk/2/hi/ health/2630869.stm [accessed 15 March 2011].
Hossler, D., Braxton, J. and Coopersmith, G. (1989) Understanding student college choice. In: Smart, J. C. (ed.), Higher education: Handbook of theory and research, Vol. 5. New York: Agathon Press.

Inglehart, R. and Welzel. C. (2005) Modernization, cultural change and democracy. New York: Cambridge University Press.

Kazaz, A., Manisali, E. and Ulubeyli, S. (2008) Effect of basic motivational factors on construction workforce productivity in Turkey, Journal of Civil Engineering and Management, 14(2), pp. 95-106. http://dx.doi.org/10.3846/13923730.2008.14.4

Kimmitt, M. C. (2009) A model of adjuncts in higher education, Economics Letters, 105(1), pp. 68-70. http://dx.doi.org/10.1016/j.econlet.2009.05.020

Kosareva, N. and Krylovas, A. (2011) A numerical experiment on mathematical model of forecasting the results of knowledge testing, Technological and Economic Development of Economy, 17(1), pp. 42-61. http://dx.doi.org/10.3846/1392 8619.2011.553994

Lee, J., Sung-Lin Hsueh, S. and Tseng, H. (2008) Utilizing data mining to discover knowledge in construction enterprise performance records, Journal of Civil Engineering and Management, 14(2), pp. 79-84.

http://dx.doi.org/10.3846/1392-3730.2008.14.2

Leichtentritt, J. and Shechtman, Z. (2009) Children with and without learning disabilities: A comparison of processes and outcomes following, Journal of Learning Disabilities, 43(2), pp. 169-179.

http://dx.doi.org/10.1177/0022219409345008

Libman, Z. (2010) Alternative assessment in higher education: An experience in descriptive statistics, Studies in Educational Evaluation, 36(12), pp. 62-68. http://dx.doi.org/10.1016/j.stueduc.2010.01.002

Lin, L., Chang, C. and Lin, Y. (2011) Structure development and performance evaluation of construction knowledge management system, Journal of Civil Engineering and Management, 17(2), pp. 184-196.

Maslow, A. H. (1954) Motivation and personality. New York: Harper.

Meek, V. L. and Wood, F. Q. (1997) The market as a new steering strategy for Australian higher education, Higher Education Policy, 10(3-4), 
pp. 253-274. http://dx.doi.org/10.1016/S09528733(97)00017-2

Mok, M. M. C. and Cheng, Y. C. (2001) A theory of self-learning in a networked human and IT environment: Implications for education reforms, International Journal of Educational Management, 15(4), pp. 172-186.

http://dx.doi.org/10.1108/09513540110394429

Park, M., Lee, H. and Kwon, S. (2010) Construction knowledge evaluation using expert index, Journal of Civil Engineering and Management, 16(3), pp. 401-411.

http://dx.doi.org/10.3846/jcem.2010.46

Pekrun, R., Elliot, A. J. and Maier, M. A. (2009) Achievement goals and achievement emotions: Testing a model of their joint relations with academic performance, Journal of Educational Psychology, 101(1), pp. 115-135.

http://dx.doi.org/10.1037/a0013383

Pekrun, R., Frenzel, A. C., Goetz, T. and Perry, R. P. (2007) The control-value theory of achievement emotions: An integrative approach to emotions in education. In: Schutz, P. A. and Pekrun, R. (Eds.), Emotions in education, San Diego: Academic Press, pp. 13-36. http://dx.doi. org/10.1016/B978-012372545-5/50003-4

Preidys, S. and Sakalauskas, L. (2010) Analysis of students' study activities in virtual learning environments using data mining methods, Technological and Economic Development of Economy, 16(1), pp. 94-108.

http://dx.doi.org/10.3846/tede.2010.06

Prestridge, S. (2012) The beliefs behind the teacher that influences their ICT practices, Computers and Education, 58(1), pp. 449-458.

http://dx.doi.org/10.1016/j.compedu.2011.08.028

Reiko, Y. (2001) University reform in the post-massification era in Japan: analysis of government education policy for the 21st century, Higher Education Policy, 14(4), pp. 277-291. http:// dx.doi.org/10.1016/S0952-8733(01)00022-8

Sánchez, J. J. C. and Alemán, E. C. (2011) Teachers' opinion survey on the use of ICT tools to support attendance-based teaching, Computers and Education, 56(3), pp. 911-915. http:// dx.doi.org/10.1016/j.compedu.2010.11.005

Sánchez, J., Salinas, A. and Harris, J. (2011) Education with ICT in South Korea and Chile, International Journal of Educational Development, 31(2), pp. 126-148. http://dx.doi. org/10.1016/j.ijedudev.2010.03.003
Strietska-Ilina, O. (Ed.) (2007) Clash of transitions: Towards a learning society. New York: Peter Lang.

Stukalina, Y. (2010) Using quality management procedures in education: Managing the learner-centered educational environment, Technological and Economic Development of Economy, 16(1), pp. 75-93.

http://dx.doi.org/10.3846/tede.2010.05

The Economist (2005) How Europe fails its young. [Online] Available at: http://www.economist. com/node/4370590?story_id=4370590 [accessed 15 December 2010].

Troiano, H., Masjuan, J. M. and Elias, M. (2007) Two decades of curricular reforms in the Spanish university, International Studies in Sociology of Education, 17(3), pp. 211-230. http://dx.doi.org/10.1080/09620210701543890

Vanderlinde, R., van Braak, J. and Dexter, S. (2012) ICT policy planning in a context of curriculum reform: Disentanglement of ICT policy domains and artifacts, Computers and Education, 58(4), pp. 1339-1350, ISSN 0360-1315. http://dx.doi. org/10.1016/j.compedu.2011.12.007

Van Vught, F. A. (1997) Combining planning and the market: An analysis of the Government strategy towards higher education in the Netherlands, Higher Education Policy, 10(3-4), pp. 211-224. http://dx.doi.org/10.1016/S09528733(97)00014-7

Vermillion, J. R., Hannafin, R. D. and Whitescarver, M. K. (2008) Using technology to promote expression and self-concept, Electronic Journal for the Integration Technology in Education, 7, pp. 22-34.

Vrontis, D., Thrassou, A. and Melanthiou, Y. (2007) A contemporary higher education studentchoice model for developed countries, Journal of Business Research, 60(9), pp. 979-989. http:// dx.doi.org/10.1016/j.jbusres.2007.01.023

West, A. and Ylönen, A. (2010) Market-oriented school reform in England and Finland: School choice, finance and governance, Educational Studies, 36(1), pp. 1-12. http://dx.doi.org/10.1080/03055690902880307

Whitty, G. (2008) Twenty years of progress?: English education policy 1988 to the present, $E d$ ucational Management Administration and Leadership, 36(2), pp. 165-184. http://dx.doi.org/10.1177/1741143207087771 
Wiseman, A. W. and Anderson, E. (2012) ICT-integrated education and national innovation systems in the Gulf Cooperation Council (GCC) countries, Computers and Education, 59(2), pp. 607-618. http://dx.doi.org/10.1016/j.compedu.2012.02.006
Wooldridge, A. (2005) The brains business, The Economist. Available at: http://www.economist.com/node/4339960 [accessed 15 December 2010] 